Research Paper: Immunology

\title{
Synergistic antibiotic effect of looped antimicrobial peptide CLP- 19 with bactericidal and bacteriostatic agents
}

\author{
Di Li ${ }^{1,2, *}$, Ya Yang ${ }^{1, *}$, Zhiqiang Tian ${ }^{3}$, Jun Lv ${ }^{1}$, Fengjun Sun ${ }^{1}$, Qian Wang ${ }^{1}$, Yao Liu ${ }^{1}$ \\ and Peiyuan Xia ${ }^{1}$ \\ ${ }^{1}$ Department of Pharmacy, Southwest Hospital, Third Military Medical University, Chongqing, China \\ ${ }^{2}$ Department of Pharmacy, Second Affiliated Hospital, Chongqing Medical University, Chongqing, China \\ ${ }^{3}$ Department of Immunology, Third Military Medical University, Chongqing, China \\ * These authors have contributed equally to this work \\ Correspondence to: Peiyuan Xia, email: py_xia2013@163.com \\ Yao Liu, email: swhliuyao@163.com
}

Keywords: antimicrobial peptides, CLP-19, synergistic effect, hydroxyl radicals, LPS, Immunology and Microbiology Section, Immune response, Immunity

Received: January 17, 2017

Accepted:April 15, 2017

Published: May 23, 2017

Copyright: Li et al. This is an open-access article distributed under the terms of the Creative Commons Attribution License 3.0 (CC BY 3.0), which permits unrestricted use, distribution, and reproduction in any medium, provided the original author and source are credited.

\section{ABSTRACT}

The treatment of drug-resistant infections is complicated and the alarming rise in infectious diseases poses a unique challenge for development of effective therapeutic strategies. Antibiotic-induced liberation of the bacterial endotoxin lipopolysaccharide (LPS) may have immediate adverse effects promoting septic shock in patients. In the present study, we first confirmed our previous finding that looped antimicrobial peptide CLP-19 exerts non-specific direct antibacterial activity with no toxic to mammalian cells and second revealed that CLP-19 has synergistic effect to enhance the antibacterial activities of other conventional bactericidal (ampicillin and ceftazidime) and bacteriostatic (erythromycin and levofloxacin) agents. Third, the underlying mechanism of antibiotic effect was likely associated with stimulation of hydroxyl radical generation. Lastly, CLP-19 was shown to effectively reduce the antibiotic-induced liberation of LPS, through direct neutralization of the LPS. Thus, CLP-19 is a potential therapeutic agent for combinatorial antibiotic therapy.

\section{INTRODUCTION}

The rapid emergence of drug-resistant bacteria endangers the efficacy of antibiotics, which presents a unique and alarming challenge to clinical care [1]. Adequate antibiotic therapy is the cornerstone of appropriate management of bacteria strains and crucial for halting the evolution of bacteria with new resistance capabilities. However, therapeutic intervention based on the conventional antibiotics alone is insufficient and possibly harmful since their use can promote the pathophysiological process of septic shock. Although the pathophysiology of septic shock is not entirely understood, it is likely due to liberation of endotoxins from the bacterial cell wall during destruction of the microorganism [2]. To overcome this obstacle, various adjuvant treatment approaches have been carefully analyzed, ranging from standard intravenous immunoglobulins or endotoxin corespecific antibodies to treatment with cytokines, cytokine receptor antagonists, or immunomodulators; the results, however, have been largely disappointing. Therefore development of a novel adjuvant treatment that not only exhibits synergistic effect in combination with existing antibacterial agents but that also relieves the excessive endotoxin-induced septic shock is a critical step in the battle against this serious threat to public health.

Antimicrobial peptides (AMPs), isolated from a wide range of species (e.g. amphibians, fish, mollusca, insects, mammals, and plants, etc.), act in host defense against pathological inflammation and microbial infections. Immunomodulators such aspolymyxin B [3], bactericidal/permeability-increasing protein $[4,5]$, CAP$18[6,7]$, and mastoparan peptide [8] may protect against lethal inflammatory response. On the other hand, ranalexin $[9,10]$, OH-CATH [11] and arenicin-1 peptide [12] may kill bacteria (both Gram-negative and Gram-positive), viruses, fungi, protozoa, and even cancerous cells. In addition, when used against many kinds of bacterial 
infections, arenicin-1 [12], ranalexin [13] and P5-18mer [13] have been shown to exert synergistic antibiotic effects.

We previously characterized the core domain of Limulus anti-LPS factor (LALF; amino acids 31-52), a small basic protein derived from the arthropods Tachypleus tridentatus and Limulus polyphemus, to generate a novel peptide, CLP-19. Composed of 19 amino acid residues, CLP-19 is head-to-tail looped via a disulfide bond and possesses cationic, amphipathic structure. The inherent potency of CLP-19 was shown to not only involve direct antibacterial activity against various pathogenic bacteria but also exert a robust anti-LPS activity that prevents the subsequent stimulation of the innate immune system activator, TLR4, as well as the successive induction of cytokines production and release [14-16].

In the present study, we sought to investigate whether co-treatments with CLP-19 and other antibiotics have the synergistic effect against bacterial growth and elucidate the underlying mechanism.

\section{RESULTS}

\section{CLP-19 displays non-selective direct antibacterial activity as compared to other conventional antibiotics}

In this assay, the minimum inhibitory concentrations (MICs) of CLP-19, ampicillin, ceftazidime, erythromycin, levofloxacin and S-LALF peptide were determined. The sensitivity of bacteria to the peptides and antibiotics is presented in Table 1. Ampicillin showed antibacterial activity against $E$. coli and $S$. aureus at MIC values of $4 \mu \mathrm{g} / \mathrm{mL}$ and $2 \mu \mathrm{g} / \mathrm{mL}$ but showed no influence on the survival of $A$. baumannii and $P$. aeruginosa, even up to $256 \mu \mathrm{g} / \mathrm{mL}$ MIC. The MIC of ceftazidime against Gramnegative and Gram-positive bacteria ranged from $0.25 \mu \mathrm{g} /$ $\mathrm{mL}$ to $16 \mu \mathrm{g} / \mathrm{mL}$. Erythromycin exhibited antibacterial activity against $S$. aureus at the MIC value of $1 \mu \mathrm{g} / \mathrm{mL}$ but showed no effect on other microbes tested, even with the highest MIC tested. The MICs of levofloxacin against $E$. coli, $S$. aureus and $P$. aeruginosa were relatively low $(0.06$ $\mu \mathrm{g} / \mathrm{mL}, 0.5 \mu \mathrm{g} / \mathrm{mL}$ and $4 \mu \mathrm{g} / \mathrm{mL}$ respectively), yet high ( $>256 \mu \mathrm{g} / \mathrm{mL}$ ) against $A$. baumannii. It is worth noting that CLP-19 showed antibacterial activity at MICs ranging from $16 \mathrm{ug} / \mathrm{mL}$ to $32 \mu \mathrm{g} / \mathrm{mL}$ against E. coli, S. aureus and $A$. baumannii, suggesting non-selective antibacterial activity for Gram-negative and Gram-positive bacteria. However, CLP-19 showed no observable antibacterial activity against $P$. aeruginosa ( $>256 \mu \mathrm{g} / \mathrm{mL})$. S-LALF, a precursor peptide of CLP-19, showed no antibacterial activity against any of the above mentioned bacteria.

\section{The therapeutic doses of CLP-19 show minimal cytotoxicity}

To evaluate the toxicity of CLP-19 in vitro, the hemolysis assay and mammalian cell toxicity assay were carried out. CLP-19 treatment at $128 \mu \mathrm{g} / \mathrm{mL}$ or lower did not produce any observable hemolysis or toxicity in erythrocytes and Vero cells; however, further increase of the peptide concentration, up to $256 \mu \mathrm{g} / \mathrm{mL}$, produced significant cytotoxicity (Table 2). Reassuringly, the concentrations of CLP-19 required for effective antibacterial activity are much less than those that showed
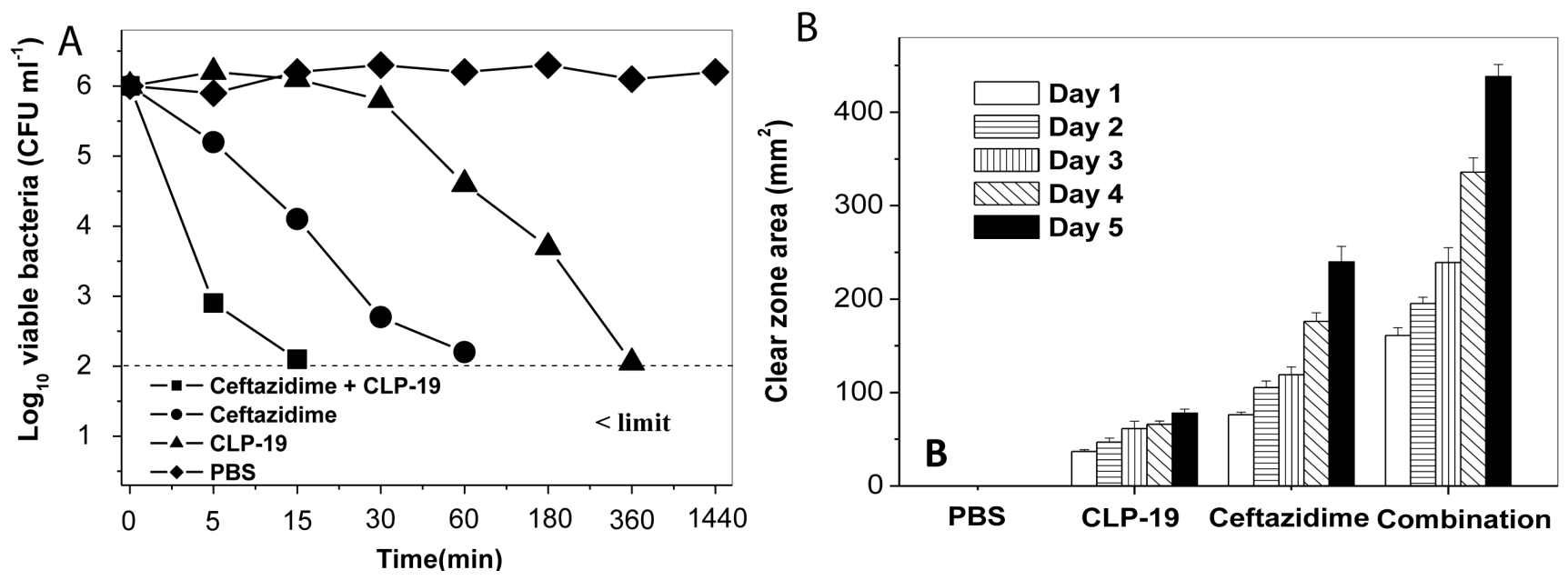

Figure 1: Synergistic characteristics of CLP-19 and the conventional antibiotics. A. E. coli strains at mid-log phase $\left(1 \times 10^{6} /\right.$ $\mathrm{mL})$ were treated with CLP-19 $(16 \mu \mathrm{g} / \mathrm{mL})$, ceftazidime $(0.25 \mu \mathrm{g} / \mathrm{mL})$ or in combination by incubating at $25{ }^{\circ} \mathrm{C}$ for $5 \mathrm{~min}, 15 \mathrm{~min}, 30$ min, 1 h, 3 h, 6 h and 24 h. Cells treated with PBS served as controls. Numerical data represent mean \pm SD $(n=3)$. B. Sterile paper discs impregnated with MICs of CLP-19 alone, ceftazidime alone or in combination were placed onto the surface of a TSA plate that had been seeded with an E. coli suspension $\left(1 \times 10^{8} / \mathrm{mL}\right)$ and incubated at $37^{\circ} \mathrm{C}$ for 5 days, with measurement of clear zones around each disc taken every 24 h. Discs impregnated with PBS served as controls. Numerical data represent mean $\pm \operatorname{SD}(n=3)$. 
Table 1: MICs of CLP-19, ampicillin, ceftazidime, erythromycin and levofloxacin against E. coli, S. aureus, A. baumannii and P. aeruginosa.

\begin{tabular}{|c|c|c|c|c|c|c|}
\hline Bacterial strains & \multicolumn{6}{|c|}{ MIC, $\mu \mathrm{g} / \mathrm{mL}$} \\
\hline E. coli & Ampicillin & Ceftazidime & Erythromycin & Levofloxacin & CLP-19 & S-LALF \\
\hline (ATCC 25922) & 4 & 0.25 & $>256$ & 0.06 & 16 & $>256$ \\
\hline $\begin{array}{l}\text { S. aureus } \\
\text { (ATCC 29213) }\end{array}$ & 2 & 16 & 1 & 0.5 & 16 & $>256$ \\
\hline $\begin{array}{l}\text { A. baumannii } \\
\text { (ATCC 19606) }\end{array}$ & $>256$ & 4 & $>256$ & $>256$ & 32 & $>256$ \\
\hline $\begin{array}{l}\text { P. aeruginosa } \\
\text { (ATCC 27853) }\end{array}$ & $>256$ & 2 & $>256$ & 4 & $>256$ & $>256$ \\
\hline
\end{tabular}

Bacterial strains at mid-log phase $\left(1 \times 10^{\%} / \mathrm{mL}\right)$ were treated with increasing concentrations of antibiotic agents with incubation at $37^{\circ} \mathrm{C}$ for $18 \mathrm{~h}$. Growth was assayed by monitoring $\mathrm{OD}_{620} . \mathrm{S}-\mathrm{LALF}$ served as control. $(n=3)$.

Table 2: Toxicity of CLP-19.

\begin{tabular}{|l|c|c|}
\hline Concentration of CLP-19 & Haemolysis, \% & Reduction in cell viability, \% \\
\hline 16 & $-1.16 \pm 0.65$ & $2.57 \pm 3.43$ \\
\hline 32 & $0.08 \pm 0.76$ & $2.04 \pm 1.60$ \\
\hline 64 & $-0.24 \pm 1.32$ & $-1.38 \pm 2.27$ \\
\hline 128 & $0.68 \pm 1.05$ & $3.39 \pm 1.44$ \\
\hline 256 & $38.71 \pm 10.05$ & $45.53 \pm 17.52$ \\
\hline 512 & $72.35 \pm 17.50$ & $91.23 \pm 30.71$ \\
\hline
\end{tabular}

Defibrinated horse blood and Vero cells were treated with CLP-19 for $4 \mathrm{~h}$ and $48 \mathrm{~h}$ respectively. PBS and 1\% sodium dodecyl sulfate were served as negative and positive controls. The negative value indicates that haemolysis was less than the PBS control and Vero cell viability was greater than the PBS control. Numerical data represent means $\pm \operatorname{SD}(n=6)$.

significant cytotoxicity to the erythrocytes and Vero cells.

\section{CLP-19 has synergistic antibacterial effect when applied in combination with other conventional antibiotics}

The synergistic effect of CLP-19 was evaluated by determining the fractional inhibitory concentration index (FICI). Table 3 shows that the average FICI of CLP19 ranged from 0.375 to 0.5 when used in combination with ampicillin, ceftazidime or levofloxacin, indicating that CLP-19 has a synergistic antibacterial effect when combining with these conventional antibiotics. Nevertheless, CLP-19 only showed a partial synergistic effect when used in combination with erythromycin (FICI $=0.75$ ) against $S$. aureus. Since the MICs of ampicillin against $A$. baumannii and $P$. aeruginosa, erythromycin against E. coli, A. baumannii and P. aeruginosa, levofloxacin against $A$. baumannii and CLP-19 against $P$. aeruginosa were not obtained because of overcoming the test concentrations, the FICIs of above mentioned compounds were not able to calculate.

\section{Synergistic characteristics of CLP-19 with the conventional antibiotics}

To investigate the synergistic antimicrobial properties of CLP-19, the killing kinetics of CLP-19 alone, ceftazidime alone, and in combination were determined. The time-killing curves suggested that treatment of CLP19 or ceftazidime alone for 60 or $360 \mathrm{~min}$ completely eliminated E. coli. Moreover, cells co-treated with CLP19 and ceftazidime showed no viable bacteria within 15 min. These findings were significantly different from the control group with PBS treatment showing minimal to no change in bacterial viability over the $24 \mathrm{~h}$ experimental period (Figure 1A).

Moreover, stability of the antibacterial activity was determined by using disc diffusion assay. Discs containing the MIC of CLP-19 for E. coli caused a $36.8 \pm$ $2.0 \mathrm{~mm}^{2}$ (mean $\pm \mathrm{SD}$ ) clear zone area on day 1 , and this zone slightly enlarged daily until $77.9 \pm 4.3 \mathrm{~mm}^{2}$ on day 5. The MIC of ceftazidime caused the clear zone area to increase from $76.1 \pm 2.9 \mathrm{~mm}^{2}$ on day 1 to $239.6 \pm 16.7$ $\mathrm{mm}^{2}$ on day 5. The clear zone area of CLP-19 combined with ceftazidime was remarkably higher, being $161.0 \pm 8.3$ $\mathrm{mm}^{2}$ on day 1 and reaching $438.2 \pm 13.0 \mathrm{~mm}^{2}$ on day 5 . These results suggested that the antibacterial compounds were active during the course of the experiment (Figure 1B). The daily increase in clear zone area caused by the compounds in combination was significantly greater $(p<$ 0.05 ) than the sum of the clear zones caused by either of the compounds individually. The similar phenomena were observed against $S$. aureus and A. baumannii (data not shown), indicating that the combination treatment has the synergistic antibacterial activity.

\section{CLP-19 or CLP-19-based combination treatments induced formation of hydroxyl radicals}

Many bactericidal antimicrobials have been known to share a common lethal pathway that involves the generation/accumulation of hydroxyl radicals [17]. 
Table 3: FICIs of CLP-19 in combination with ampicillin, ceftazidime, erythromycin or levofloxacin.

\begin{tabular}{|l|c|c|c|c|c|c|c|c|}
\hline \multirow{2}{*}{ Bacterial strains } & \multicolumn{2}{|l|}{ Ampicillin+CLP-19 } & \multicolumn{2}{l|}{ Ceftazidime+CLP-19 } & \multicolumn{2}{|l|}{ Erythromycin+CLP-19 } & \multicolumn{2}{|l|}{ Levofloxacin+CLP-19 } \\
\cline { 2 - 9 } & FICI & $\begin{array}{l}\text { Interactive } \\
\text { category }\end{array}$ & FICI & $\begin{array}{l}\text { Interactive } \\
\text { category }\end{array}$ & FICI & $\begin{array}{l}\text { Interactive } \\
\text { category }\end{array}$ & FICI & $\begin{array}{l}\text { Interactive } \\
\text { category }\end{array}$ \\
\hline $\begin{array}{l}\text { E. coli } \\
\text { (ATCC 25922) }\end{array}$ & 0.375 & $\mathrm{~S}$ & 0.5 & $\mathrm{~S}$ & $\backslash$ & $\backslash$ & 0.5 & $\mathrm{~S}$ \\
\hline $\begin{array}{l}\text { S. aureus } \\
\text { (ATCC 29213) }\end{array}$ & 0.5 & $\mathrm{~S}$ & 0.5 & $\mathrm{~S}$ & 0.75 & $\mathrm{PS}$ & 0.5 & $\mathrm{~S}$ \\
\hline $\begin{array}{l}\text { A. baumannii } \\
\text { (ATCC 19606) }\end{array}$ & $\backslash$ & $\backslash$ & 0.5 & $\mathrm{~S}$ & $\backslash$ & $\backslash$ & $\backslash$ & $\backslash$ \\
\hline
\end{tabular}

A 2-dimensional checkerboard with 2-fold dilutions of each agent was set up. The FICI was calculated according to the equation: $\mathrm{FICA}+\mathrm{FICB}=\left(\mathrm{MIC}_{\text {Drug A }}\right.$ in combination/MIC $\left.\mathrm{Mrug}_{\text {Alone }}\right)+\left(\mathrm{MIC}_{\text {Drug B }}\right.$ in combination/MIC ${ }_{\text {Drug B }}$ alone $)$. FICI, calculated as the sum of each FIC, was interpreted as follows: FICI $<0.5$, synergy; $0.5 \leq \mathrm{FICI}<1$, partial synergy; $1 \leq$ FICI $<4$, additive effect or indifference; $4 \leq$ FICI antagonism. S denotes synergy and PS denotes partial synergy. $(n=3)$.

To explore this idea, we sought to determine whether any of the various CLP-19 and conventional antibiotic combinations was capable of generating hydroxyl radicals. Assay with dye30-(p-hydroxyphenyl) fluorescein (HPF), a cell-permeable fluorescence probe that selectively detects highly reactive oxygen species such as hydroxyl radicals, showed that treatment of CLP-19, ampicillin or ceftazidime alone significantly generated hydroxyl radicals by $>60 \%$ against $E$. Coli. However, levofloxacin alone only generated hydroxyl radicals by $<10 \%$. When the combination treatments were applied the hydroxyl radicals significantly increased $(p<0.05)$ for ampicillin, ceftazidime or levofloxacin (Figure 2A). Tests against the $S$. aureus strains showed similar effects when the combination treatments were applied using the three above antibiotic agents $(p<0.05)$. Additionally, the low level of hydroxyl radicals produced by the erythromycin treatment was enhanced by CLP-19 $(p>0.05)$, which may elucidate our previous observation of only a partial synergistic effect between CLP-19 and erythromycin against S.aureus (Figure 2B). Meanwhile, the marked increasing of hydroxyl radicals $(p<0.05)$ was also observed when CLP19 in combination with ceftazidime against $A$. baumannii (data not shown).

\section{CLP-19 or CLP-19-based combination treatments induced catabolic NADH depletion}

To understand the mechanism underlying the formation of hydroxyl radicals, the depletion of NADH stimulated by CLP-19, ceftazidime and their combination was investigated by measuring the $\mathrm{NAD}^{+} / \mathrm{NADH}$ ratios. The results showed that CLP-19 or ceftazidime alone markedly increased the $\mathrm{NAD}^{+} / \mathrm{NADH}$ ratio of the various bacterial organisms tested by $>3$ - to 7 -fold at $0.5 \mathrm{~h}$ after
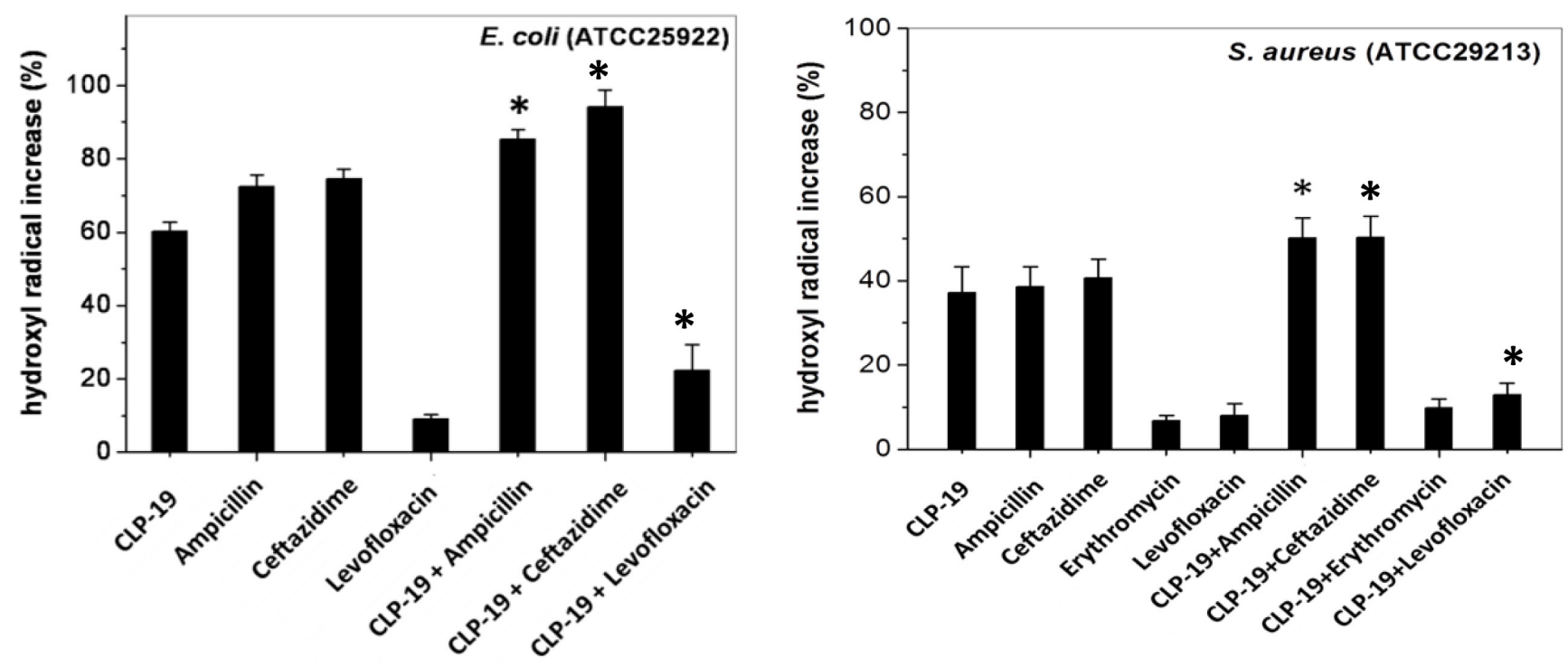

Figure 2: Formation of hydroxyl radicals induced by CLP-19 or CLP-19-based combination. Bacteria strains at mid$\log$ phase $\left(1 \times 10^{6} / \mathrm{mL}\right)$ were treated with MICs of CLP-19 alone or ampicillin, ceftazidime, erythromycin or levofloxacin alone or in combination with CLP-19 by incubating at $37^{\circ} \mathrm{C}$ for $2 \mathrm{~h}$. Cells treated with PBS served as controls. Numerical data represent mean \pm SD $(n=3) . * p<0.05 v s$. conventional antibiotics alone. 
the agents were added. Notably, more than 6- to 9-fold in the $\mathrm{NAD}^{+} / \mathrm{NADH}$ ratios were occurred in response to treatment of CLP-19 in combination with ceftazidime at $0.5 \mathrm{~h}$ after the agents were added, but the $\mathrm{NAD}^{+} / \mathrm{NADH}$ ratio values returned to levels indistinguishable from initial values by the $1 \mathrm{~h}$ post-treatment time point. These changes were not observed in the untreated control group, wherein the $\mathrm{NAD}^{+} / \mathrm{NADH}$ ratio remained relatively consistent (Figure 3).

\section{CLP-19 attenuates antibiotic-induced LPS release}

The concentration of LPS in supernatants was measured to investigate the effect of CLP-19 on antibiotic-liberated LPS release. The CLP-19-treated cultures showed the lowest concentrations of LPS, and ceftazidime treatment led to significant LPS liberation at $2 \times$ MIC. However, when bacterial cells were treated with
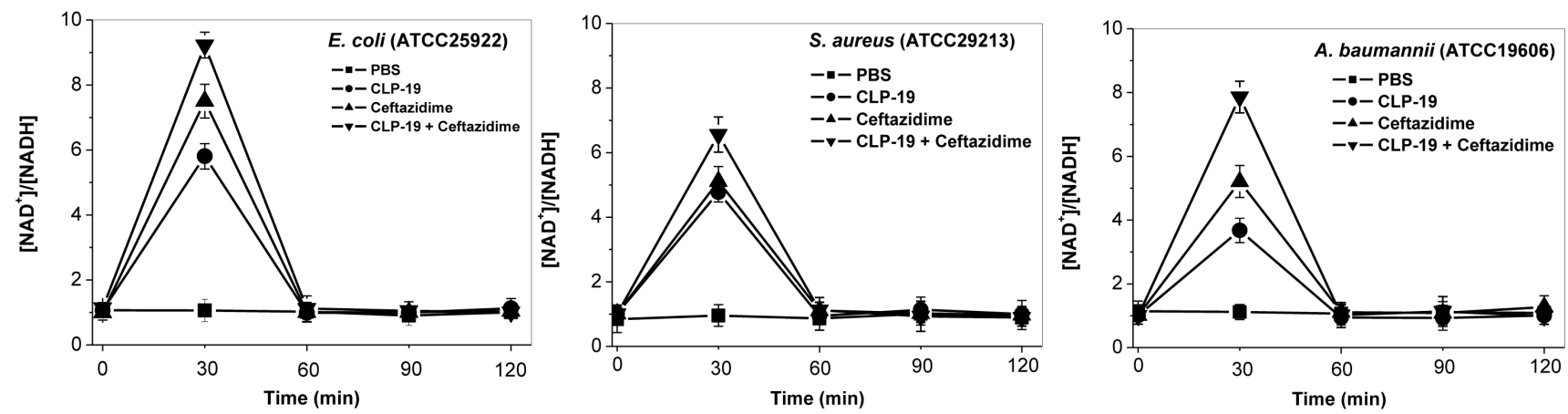

Figure 3: Catabolic NADH depletion induced by CLP-19 alone, ceftazidime alone or the combination treatment. Bacterial cells at the mid-log phase $\left(1 \times 10^{6} / \mathrm{mL}\right)$ were treated with MICs of CLP-19 alone, ceftazidime alone or in combination, and then were collected by centrifugation at $13000 \mathrm{rpm}$ for $1 \mathrm{~min}$ at every half hour between 0 and $2 \mathrm{~h}$. The NAD cycling assay was performed in 96-well plates and the $\mathrm{OD}_{570}$ was recorded within $10 \mathrm{~min}$. NAD ${ }^{+}$and NADH standards ranging between 0.0375 and $0.75 \mathrm{nM}$ were used to calibrate the assay. Cells treated with PBS served as controls. Numerical data represent mean $\pm \operatorname{SD}(n=3)$.

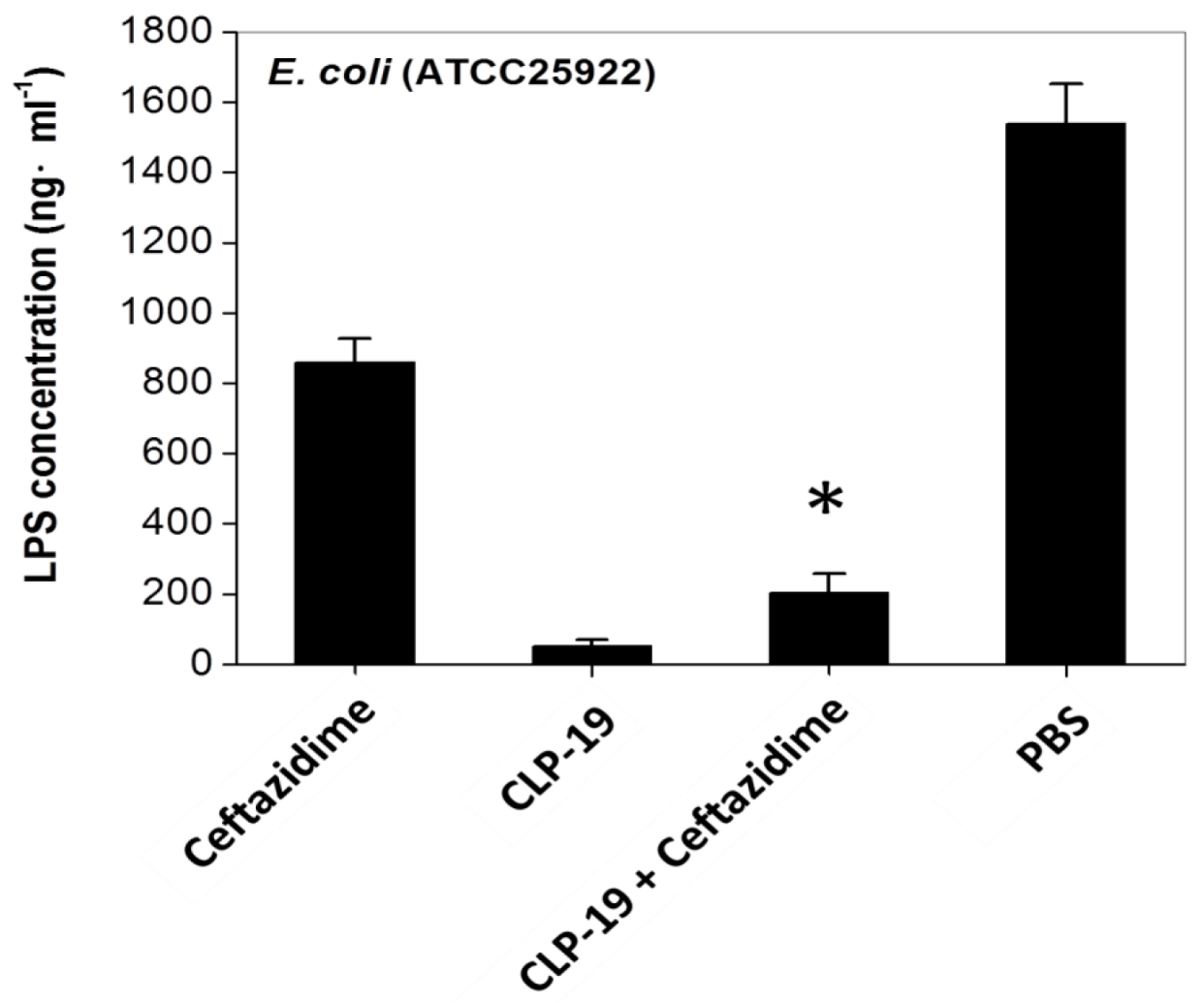

Figure 4: Influence of CLP-19 on antibiotic-induced LPS endotoxin release. Bacterial cells at the mid-log phase $\left(1 \times 10^{4} / \mathrm{mL}\right)$ were treated with $2 \times$ MICs of CLP-19 alone, ceftazidime alone or in combination by incubation at $37^{\circ} \mathrm{C}$ for $6 \mathrm{~h}$. The filtrates of cultures were serially diluted and reacted to the LAL reagent. Kinetic turbidity was measured using an ATi-321 tube reader. The PBS treated bacterial cells served as controls. Numerical data represent mean $\pm \operatorname{SD}(n=3) . * p<0.05 v s$. ceftazidime. 
the combination of ceftazidime and CLP-19, the release of LPS was decreased tremendously $(p<0.05)$, and this was in contrast to the PBS-treated control cultures showing the highest concentrations of liberated LPS were found in supernatants (Figure 4).

\section{DISCUSSION}

Drug-resistant bacterial infections have a high mortality rate and the treatment process is difficult since the conventional antibacterial drugs have reduced efficacy or are completely inefficacious. Alternative novel antibacterial agents or combination antibiotic therapy are considered to a promising strategy for overcoming this obstacle. The present study confirmed our previous finding that CLP-19 exhibits a robust antibacterial activity against Gram-positive and Gram-negative bacteria. Intriguingly, a significant synergistic effect with higher potency, faster killing kinetics and longer antibacterial duration was observed when CLP-19 was applied in combination with other bactericidal and bacteriostatic antibiotics, and these findings were in accord with other AMPs or antibacterial agents [18-21].

However, not all combinations exert synergistic effect. For instance, the bacteriostatic antibiotics were discovered to impair the AMPs-mediated bacteria killing by depolarization the transmembrane potential [22]. In our investigation, CLP-19 exhibits non-specific activity regardless of the Gram-status and produces a synergistic effect hints that CLP-19 possibly shares another killing or synergy mechanism. Previous reports showed that antibacterial agents induced highly deleterious hydroxyl radical production, suggesting oxidative stress acts as the trigger inducing bacterial cell death $[17,23]$. Our further mechanism research is in agreement with these studies that CLP-19 and CLP-19-based combination significantly increase the generation of hydroxyl radicals from bacteria through transiently boosting $\mathrm{NAD}^{+}$production (or depleted NADH), which are closely associated with the direct and synergistic antibacterial effect of CLP-19, rather than a consequence of bacterial killing.

Moreover, the antibiotic-induced liberation of LPS, especially by some classes of $\beta$-lactam antibiotics such as ceftazidime against Gram-negative bacilli, has been shown to be associated with rapid clinical deterioration of patients [24, 25]. Our previous work have revealed that CLP-19 in the extracellular space can bind directly to LPS and competitively inhibit formation of the LPS/ LBP complex, thereby preventing the subsequent TLR4 activation and successive induction of cytokines [14]. Therefore, ceftazidime and $E$. coli were employed to set up models to detect the anti-LPS activity of CLP-19based combination. Provocatively, our present finding demonstrates that the direct anti-LPS activity of CLP-19 contributes to relief of antibiotic-induced LPS liberation and successive fatal adverse effects.
In conclusion, our investigation showed the compelling direct antibacterial activity and synergism with bactericidal and bacteriostatic antibiotics. More importantly, treatment of CLP-19 is able to reduce other conventional antibiotic-induced liberation of LPS. We therefore revealed that CLP-19 is a potential therapeutic agent and adjuvant for treatment of bacterial infection.

\section{MATERIALS AND METHODS}

\section{Preparation of peptides}

$\begin{array}{lllr}\text { The head-to-tail-looped peptide } & \text { CLP- } \\ 19 & \text { (CRKPTFRRLKWKIKFKFKC; } & \text { molecular } \\ \text { mass, } 2511.1 & \text { Da) and S-LALF } & \text { peptide }\end{array}$ (CHYRIKPTFRRLKWKYKGKFWC; molecular mass, 2945.5 Da) were synthesized by the Symphony Peptide Synthesizer (Protein Technologies, Tucson, AZ, USA) using a stepwise solid-phase peptide assembly procedure. The synthesis of peptide CLP-19 was started with an Fmoc-Lys(Boc)-Wang resin. After drying, the peptides were cleaved and purified by trifluoroacetic acid mixture solution and HPLC (Shen Zhen Hybio Engineering, Shenzhen, China) to achieve a purity of $98.4 \%$ for CLP19 and $99.2 \%$ for S-LALF.

\section{Antibiotics, bacterial strains and culture conditions}

Ampicillin, ceftazidime, erythromycin and levofloxacin were purchased from Sigma-Aldrich (St. Louis, MO, USA). E. coli (ATCC 25922), S. aureus (ATCC 29213), A. baumannii (ATCC 19606), and $P$. aeruginosa (ATCC 27853) were obtained from the American Type Culture Collection (Manassas, VA, USA). The pathogenic bacteria were grown in Difco Luria Bertani (LB) medium at $37^{\circ} \mathrm{C}$.

\section{Antibacterial activity assay}

Bacterial strains were cultured in Mueller-Hinton $(\mathrm{MH})$ broth and concentration of the bacteria suspensions were adjusted to obtain standardized populations by measuring the turbidity with a SpectraMax M2e spectrophotometer (Molecular Devices, Sunnyvale, CA, USA). At mid-log phase, the bacterial strains $\left(1 \times 10^{6} / \mathrm{mL}\right)$ were inoculated into $\mathrm{MH}$ broth and the mixture $(0.1 \mathrm{~mL})$ was dispensed into 96-well microtiter plates. Susceptibility testing was performed by broth microdilution of the test compounds, as recommended by guidelines of the Clinical and Laboratory Standards Institute (CLSI) (2015). Briefly, after $18 \mathrm{~h}$ of incubation at $37^{\circ} \mathrm{C}$, the MIC and growth was assayed by monitoring optical density at $620 \mathrm{~nm}\left(\mathrm{OD}_{620}\right)$. 


\section{Haemolysis assay}

Defibrinated horse blood (2\%, Oxoid, Basingstoke, UK) and CLP-19 were co-incubated in PBS buffers at defined $\mathrm{pH} 7.4$ (35 $\mathrm{mM}$ phosphate buffer/150 $\mathrm{mM} \mathrm{NaCl})$. Following incubation in a microplate spectrophotometerat $37^{\circ} \mathrm{C}$ for $4 \mathrm{~h}$, the amount of hemoglobin released was spectrophotometrically measured with $\mathrm{A}_{570}$ readings every $2 \mathrm{~min}$. The measurement was then quantified relative to positive control samples lysed with $1 \%$ sodium dodecyl sulfate, which leads to $100 \%$ haemolysis. A reduction in the $\mathrm{A}_{570}$ reading indicated hemolysis.

\section{Mammalian cell toxicity assay}

Vero cells were obtained from the Department of Immunology at the Third Military Medical University (Chongqing, China) and cultured in RPMI 1640 (Invitrogen, Shanghai, China) supplemented with 10\% fetal bovine serum (TBD Sciences, Tianjing, China), 100 $\mathrm{U} / \mathrm{mL}$ penicillin and $100 \mathrm{U} / \mathrm{mL}$ streptomycin (Beyotime, Jiangsu, China) at $37^{\circ} \mathrm{C}$ under $5 \% \mathrm{CO}_{2}[26,27]$. Cells were harvested by $0.05 \%$ trypsin to prepare single cell suspension, seeded in 96-well plates and cultured for 24 $\mathrm{h}$ prior to treatment of CLP-19. An increasing amount of CLP-19 was added and cells were incubated for another $48 \mathrm{~h}$. After washing, cells were further cultured in fresh medium containing $100 \mathrm{mg} / \mathrm{L}$ neutral red for 90 min prior to a PBS wash. Then cells were treated with $200 \mu \mathrm{L}$ of acidified isopropanol $(0.33 \% \mathrm{HCl})$, and the viability was assessed with $\mathrm{A}_{540}$. A reduction in $\mathrm{A}_{540}$ values indicate reduced cell viability.

\section{Combination assay}

The overall antibacterial effect of CLP-19 in combination with the conventional antibiotics was investigated by checkerboard analysis via readout of the FICI. FICI was calculated according to the equation: $\mathrm{FIC}_{\mathrm{A}}+\mathrm{FIC}_{\mathrm{B}}$, where $\mathrm{FIC}_{\mathrm{A}}$ was $\left[\left(\mathrm{MIC}_{\mathrm{Drug}} \mathrm{A}\right.\right.$ in combination $) /\left(\mathrm{MIC}_{\text {Drug A }}\right.$ alone $\left.)\right]$ and $\mathrm{FIC}_{\mathrm{B}}$ was [ $\left(\mathrm{MIC}_{\text {Drug B }}\right.$ in combination $) /\left(\mathrm{MIC}_{\mathrm{Drug}} \mathrm{B}\right.$ alone $\left.)\right][28,29]$. The resultant values were interpreted as follows: $\mathrm{FICI}<0.5$, synergy; $0.5 \leq$ FICI $<1$, partial synergy; $1 \leq$ FICI $<4$, additive effect or indifference; $4 \leq$ FICI, antagonism [30]. A2dimensional checkerboard with 2-fold dilutions of each agent was set up following the CLSI guidelines (2015). Growth control wells containing medium and no antibiotic agents were included in each plate. Each test was performed in triplicate.

\section{Antibacterial kinetics assay}

Bacteria suspension at mid-log phase $\left(1 \times 10^{6} \%\right.$ $\mathrm{mL}$ ) was plated in 96-well microtiter plates and treated with CLP-19, ceftazidime, or co-treated with CLP-19 and ceftazidime. After incubation at $25^{\circ} \mathrm{C}$ for $5 \mathrm{~min}, 15$ $\min , 30 \mathrm{~min}, 1 \mathrm{~h}, 3 \mathrm{~h}, 6 \mathrm{~h}$ and $24 \mathrm{~h}$, the amounts of viable bacteria were determined by serial dilution in PBS and plating on trypticase soy agar (TSA) plates with $24 \mathrm{~h}$ of incubation at $37^{\circ} \mathrm{C}$. The detection limit for each well was $100 \mathrm{CFU} / \mathrm{mL}$.

\section{Disc diffusion assay}

To assess the temporal stability of the antibacterial actions of CLP-19 alone, ceftazidime alone and the combined treatment, sterile paper discs (AA, diameter 6 $\mathrm{mm}$; Whatman International Ltd, Maidstone, Kent, UK) were impregnated with MICs of each or with PBS only as a control. Discs were dried for $3 \mathrm{~h}$ at $25^{\circ} \mathrm{C}$ and placed onto the surface of a TSA plate that had been seeded with $100 \mu \mathrm{L}$ of $E$. coli suspension $\left(1 \times 10^{8} / \mathrm{mL}\right.$; spread to achieve a semi-confluent lawn of growth) and allowed to dry for $3 \mathrm{~h}$ at $37^{\circ} \mathrm{C}$. The plates were then incubated for 5 days at $37^{\circ} \mathrm{C}$ and inspected every $24 \mathrm{~h}$ for the appearance of clear zones around each disc, which were measured with a ruler. Growth inhibition was calculated according to the equation: [(total clear zone area)-(area of the disc)].

\section{Hydroxyl radical formation assay}

Bacteria $\left(1 \times 10^{6} / \mathrm{mL}\right)$ were treated with MICs of CLP-19, ampicillin, ceftazidime, erythromycin, levofloxacin or CLP-19 in combination with each conventional antibiotic, and PBS served as controls. All experimental groups were incubated at $37^{\circ} \mathrm{C}$ for $2 \mathrm{~h} .5$ $\mathrm{mM}$ of fluorescent reporter dye30-(p-hydroxyphenyl) fluorescein (HPF) (Invitrogen) was subsequently added. The fluorescence intensity of HPF was measured by a spectrofluorophotometer at $490 \mathrm{~nm}$ excitation and $515 \mathrm{~nm}$ emission wavelengths. The percentage of hydroxyl radical formation was calculated based on an equation: $\left[\left(\mathrm{OD}_{490}\right.\right.$ of well treated with antibacterial agent)-( $\left(\mathrm{OD}_{490}\right.$ of non-treated control $)] /\left(\mathrm{OD}_{490}\right.$ of non-treated control $) \times 100$.

\section{$\mathrm{NAD}^{+}, \mathbf{N A D H}$ extraction}

Dinucleotide extraction and the cycling assay were performed, as previously described [31]. Bacteria at the mid-log phase $\left(1 \times 10^{6} / \mathrm{mL}\right)$ were centrifuged at 13000 $\mathrm{rpm}$ for $5 \mathrm{~min}$ and resuspended in $1 \mathrm{~mL}$ of LB. For NAD ${ }^{+}$ and NADH extraction, bacteria samples were collected by centrifugation (13000 rpm for $1 \mathrm{~min}$ ) at every half hour between 0 and $2 \mathrm{~h}$ after addition of MICs of CLP- 
19, ceftazidime, or in combination. The supernatant was removed and the pellets were frozen immediately in a dry ice-ethanol bath and stored at $-80^{\circ} \mathrm{C}$ until all samples had been collected. Analysis of the ice-cold pellets was initiated by adding a $75 \mu \mathrm{L}$ of $0.2 \mathrm{M} \mathrm{NaOH}$ (for $\mathrm{NADH}$ extraction) or $75 \mu \mathrm{L}$ of $0.2 \mathrm{M} \mathrm{HCl}$ (for $\mathrm{NAD}^{+}$extraction), after which the samples were heated for $10 \mathrm{~min}$ at $100^{\circ} \mathrm{C}$ and then centrifuged at $10000 \mathrm{rpm}$ for $5 \mathrm{~min}$. The $\mathrm{NAD}^{+} /$ NADH-containing supernatants were transferred to fresh tubes and stored in the dark on ice until use in the cycling assay.

The $\mathrm{NAD}^{+}$cycling assay was performed in 96-well plates. The respective reaction mixtures contained 16 $\mu \mathrm{L}$ of 1.0 M bicine ( $\mathrm{pH}$ 8.0) (Sigma-Aldrich), $40 \mu \mathrm{L}$ of sample extract, $40 \mu \mathrm{L}$ of neutralizing buffer $(0.1 \mathrm{M} \mathrm{HCl}$ for $\mathrm{NADH}$ or $0.1 \mathrm{M} \mathrm{NaOH}$ for $\mathrm{NAD}^{+}$), $16 \mu \mathrm{L}$ of $100 \%$ ethanol, and $30 \mu \mathrm{L}$ of $40 \mathrm{mM}$ EDTA ( $\mathrm{pH} 8.0$ ). When the reaction mixtures were aliquoted in the wells, $16 \mu \mathrm{L}$ phenazine ethosulfate (PES) (Sigma-Aldrich) and $16 \mu \mathrm{L}$ 3- [4,5-dimethylthiazol-2-yl]-2,5-diphenyltetrazolium bromide (MTT) (Sigma-Aldrich) were added and the plates were incubated for $3 \mathrm{~min}$ at $30^{\circ} \mathrm{C}$. Then, $3.2 \mu \mathrm{L}$ of alcohol dehydrogenase ( $500 \mathrm{U} / \mathrm{mL}$; Sigma-Aldrich) in bicine buffer $(\mathrm{pH} 8.0)$ were added to the reaction mixture to initiate the reaction and the increase in absorbance at $570 \mathrm{~nm}$ over the next $10 \mathrm{~min}$ was recorded. The rate of MTT reduction is proportional to the concentration of $\mathrm{NAD}^{+}$or $\mathrm{NADH}$ in the sample, and $\mathrm{NAD}^{+}$and $\mathrm{NADH}$ standards (range:0.0375 and $0.75 \mathrm{nM}$; Sigma-Aldrich) were used to calibrate the assay.

\section{Endotoxin release studies}

Bacteria at the mid-log phase $\left(1 \times 10^{4} / \mathrm{mL}\right)$ were treated with $2 \times \mathrm{MICs}$ of CLP-19, ceftazidime, or in combination for $6 \mathrm{~h}$ at $37^{\circ} \mathrm{C}$. Bacteria treated with PBS served as controls. The samples were filtered through a pyrogen-free 0.2-pm pore polysulphone filter (Acrodisc; Gelman Scientific, Northampton, UK) and the filtrates were stored immediately at $-70^{\circ} \mathrm{C}$ until use. For analysis, the filtrates were thawed at room temperature, serially diluted with pyrogen-free water (range: $10^{2}$ - to $10^{4}$-fold) and reacted with Limulus amebocytelysate (LAL) reagent (1:1 ratio). Kinetic turbidity was measured using an ATi321 tube reader (Lab Kinetics, Somerset, UK).

\section{Statistical analysis}

Data are expressed as the mean of at least three independent experiments \pm standard deviation. Statistical significance was determined by paired Student $t$ test if compared only two groups or one-way ANOVA followed by what test if analyzing more than two groups. Differences were considered to be statistically significant at $P<0.05$ [32].

\section{CONFLICTS OF INTEREST}

The authors declare no conflict of interest.

\section{FINANCIAL SUPPORT}

This work was supported by grants from the Natural Science Foundation of China (Nos. 81402937, 81173102 and 81473222), the National Key Sci-Tech Special Project of China (No. 2012ZX09102101-012), and the Science and Technology Research Projects of the Chongqing Science and Technology Committee of China (No. cstc2013yykfA10006).

\section{REFERENCES}

1. Falagas ME, Grammatikos AP, Michalopoulos A. Potential of old-generation antibiotics to address current need for new antibiotics. Expert Rev Anti Infect Ther. 2008; 6:593-600.

2. Lepper PM, Held TK, Schneider EM, Bolke E, Gerlach H, Trautmann M. Clinical implications of antibiotic-induced endotoxin release in septic shock. Intensive Care Med. 2002; 28:824-833.

3. Takeyama N, Noguchi H, Hirakawa A, Kano H, Morino K, Obata T, Sakamoto T, Tamai F, Ishikura H, Kase Y, Kobayashi M, Naka T, Takahashi Y, et al. Time to initiation of treatment with polymyxin B cartridge hemoperfusion in septic shock patients. Blood Purif. 2012; 33:252-256.

4. Schultz H, Weiss JP. The bactericidal/permeabilityincreasing protein (BPI) in infection and inflammatory disease. Clin Chim Acta. 2007; 384:12-23.

5. Weiss J. Bactericidal/permeability-increasing protein (BPI) and lipopolysaccharide-binding protein (LBP): structure, function and regulation in host defence against Gramnegative bacteria. Biochem Soc Trans. 2003; 31:785-790.

6. Nijnik A, Pistolic J, Wyatt A, Tam S, Hancock RE. Human cathelicidin peptide LL-37 modulates the effects of IFNgamma on APCs. J Immunol. 2009; 183:5788-5798.

7. Filewod NC, Pistolic J, Hancock RE. Low concentrations of LL-37 alter IL-8 production by keratinocytes and bronchial epithelial cells in response to proinflammatory stimuli. FEMS Immunol Med Microbiol. 2009; 56:233-240.

8. Lentschat A, Karahashi H, Michelsen KS, Thomas LS, Zhang W, Vogel SN, Arditi M. Mastoparan, a G protein agonist peptide, differentially modulates TLR4- and TLR2mediated signaling in human endothelial cells and murine macrophages. J Immunol. 2005; 174:4252-4261.

9. Desbois AP, Lang S, Gemmell CG, Coote PJ. Surface disinfection properties of the combination of an antimicrobial peptide, ranalexin, with an endopeptidase, lysostaphin, against methicillin-resistant Staphylococcus aureus (MRSA). J Appl Microbiol. 2010; 108:723-730.

10. Desbois AP, Sattar A, Graham S, Warn PA, Coote PJ. MRSA decolonization of cotton rat nares by a combination 
treatment comprising lysostaphin and the antimicrobial peptide ranalexin. J Antimicrob Chemother. 2013; 68:25692575.

11. Zhang BY, Li SM, Gao ZH, Shen JH. Protective effects of snake venom antimicrobial peptide $\mathrm{OH}-\mathrm{CATH}$ on E. coli induced rabbit urinary tract infection models. Zoological research. 2013; 34:27-32.

12. Choi H, Lee DG. Synergistic effect of antimicrobial peptide arenicin-1 in combination with antibiotics against pathogenic bacteria. Res Microbiol. 2012; 163:479-486.

13. Jeong N, Kim JY, Park SC, Lee JK, Gopal R, Yoo S, Son BK, Hahm JS, Park Y, Hahm KS. Antibiotic and synergistic effect of Leu-Lys rich peptide against antibiotic resistant microorganisms isolated from patients with cholelithiasis. Biochem Biophys Res Commun. 2010; 399:581-586.

14. Ren JD, Gu JS, Gao HF, Xia PY, Xiao GX. A synthetic cyclic peptide derived from Limulus anti-lipopolysaccharide factor neutralizes endotoxin in vitro and in vivo. Int Immunopharmacol. 2008; 8:775-781.

15. Li D, Liu Y, Yang Y, Chen JH, Yang J, Zou LY, Tian ZQ, Lv J, Xia PY. Looped host defense peptide CLP-19 binds to microtubules and inhibits surface expression of TLR4 on mouse macrophages. J Immunol. 2013; 190:6083-6092.

16. Liu Y, Ni B, Ren JD, Chen JH, Tian ZQ, Tang M, Li D, Xia P. Cyclic Limulus anti-lipopolysaccharide (LPS) factor-derived peptide CLP-19 antagonizes LPS function by blocking binding to LPS binding protein. Biol Pharm Bull. 2011; 34:1678-1683.

17. Nguyen D, Joshi-Datar A, Lepine F, Bauerle E, Olakanmi O, Beer K, McKay G, Siehnel R, Schafhauser J, Wang Y, Britigan BE, Singh PK. Active starvation responses mediate antibiotic tolerance in biofilms and nutrient-limited bacteria. Science. 2011; 334:982-986.

18. Cirioni O, Silvestri C, Ghiselli R, Orlando F, Riva A, Mocchegiani F, Chiodi L, Castelletti S, Gabrielli E, Saba V, Scalise G, Giacometti A. Protective effects of the combination of alpha-helical antimicrobial peptides and rifampicin in three rat models of Pseudomonas aeruginosa infection. J Antimicrob Chemother. 2008; 62:1332-1338.

19. Yenugu S, Narmadha G. The human male reproductive tract antimicrobial peptides of the HE2 family exhibit potent synergy with standard antibiotics. J Pept Sci. 2010; 16:337341.

20. Dhand A, Bayer AS, Pogliano J, Yang SJ, Bolaris M, Nizet V, Wang G, Sakoulas G. Use of Antistaphylococcal b-Lactams to Increase Daptomycin Activity in Eradicating Persistent Bacteremia Due to Methicillin-Resistant Staphylococcus aureus: Role of Enhanced Daptomycin Binding. Clin Infect Dis. 2011; 53:158-163.
21. Lin L, Nonejuie P, Munguia J, Hollands A, Olson J, Dam Q, Kumaraswamy M, Rivera H Jr, Corriden R, Rohde M, Hensler ME, Burkart MD, Pogliano J, et al. Azithromycin Synergizes with Cationic Antimicrobial Peptides to Exert Bactericidal and Therapeutic Activity Against Highly Multidrug-Resistant Gram-Negative Bacterial Pathogens. EBioMedicine. 2015; 2:690-698.

22. Kristian SA, Timmer AM, Liu GY, Lauth X, Sal-Man N, Rosenfeld Y, Shai Y, Gallo RL, Nizet V. Impairment of innate immune killing mechanisms by bacteriostatic antibiotics. FASEB J. 2007; 21:1107-1116.

23. Kohanski MA, Dwyer DJ, Hayete B, Lawrence CA, Collins JJ. A common mechanism of cellular death induced by bactericidal antibiotics. Cell. 2007; 130:797-810.

24. Tsuji M, Matsuda H, Miwa H, Miyazaki S. Antimicrobialinduced release of endotoxin from Pseudomonas aeruginosa: comparison of in vitro and animal models. $\mathrm{J}$ Antimicrob Chemother. 2003; 51:353-359.

25. Zhang H, Niesel DW, Peterson JW, Klimpel GR. Lipoprotein release by bacteria: potential factor in bacterial pathogenesis. Infect Immun. 1998; 66:5196-5201.

26. Feng ZC, Riopel M, Li J, Donnelly L, Wang R. Downregulation of Fas activity rescues early onset of diabetes in c-Kit( $\mathrm{Wv} /+)$ mice. Am J Physiol Endocrinol Metab. 2013; 304:E557-565.

27. Feng ZC, Popell A, Li J, Silverstein J, Oakie A, Yee SP, Wang R. c-Kit receptor signaling regulates islet vasculature, beta-cell survival, and function in vivo. Diabetes. 2015; 64:3852-3866.

28. Pankey GA, Ashcraft DS. In vitro synergy of ciprofloxacin and gatifloxacin against ciprofloxacin-resistant Pseudomonas aeruginosa. Antimicrob Agents Chemother. 2005; 49:2959-2964.

29. Pankey G, Ashcraft D, Patel N. In vitro synergy of daptomycin plus rifampin against Enterococcus faecium resistant to both linezolid and vancomycin. Antimicrob Agents Chemother. 2005; 49:5166-5168.

30. Odds FC. Synergy, antagonism, and what the chequerboard puts between them. J Antimicrob Chemother. 2003; 52:1.

31. Cui Y, Zhao Y, Tian Y, Zhang W, Lv X, Jiang X. The molecular mechanism of action of bactericidal gold nanoparticles on Escherichia coli. Biomaterials. 2012; 33:2327-2333.

32. Feng ZC, Li J, Turco BA, Riopel M, Yee SP, Wang R. Critical role of c-Kit in beta cell function: increased insulin secretion and protection against diabetes in a mouse model. Diabetologia. 2012; 55:2214-2225. 